\title{
Genome profiling of chronic myelomonocytic leukemia: frequent alterations of RAS and RUNXI genes
}

Véronique Gelsi-Boyer ${ }^{\dagger 1,2,3}$, Virginie Trouplin ${ }^{\dagger 1,2}$, José Adélaïde ${ }^{\dagger 1}$, Nicola Aceto ${ }^{4}$, Virginie Remy ${ }^{1}$, Stephane Pinson" ${ }^{5}$, Claude Houdayer6, Christine Arnoulet ${ }^{2}$, Danielle Sainty ${ }^{2}$, Mohamed Bentires-Alj ${ }^{4}$, Sylviane Olschwang1,2, Norbert Vey ${ }^{7}$, Marie-Joëlle Mozziconacci1,2, Daniel Birnbaum*1 and Max Chaffanet ${ }^{1}$

Address: ${ }^{1}$ Centre de Recherche en Cancérologie de Marseille, Laboratoire d'Oncologie Moléculaire, UMR891 Inserm, Institut Paoli-Calmettes, Marseille, France, ${ }^{2}$ Département de BioPathologie, Institut Paoli-Calmettes, Marseille, France, ${ }^{3}$ Université de la Méditerranée, Marseille, France, ${ }^{4}$ Friedrich Miescher Institute for Biomedical Research, Basel, Switzerland, ${ }^{5}$ Service de génétique clinique et moléculaire, Hôpital Edouard Herriot, Lyon, France, ${ }^{6}$ Laboratoire de génétique constitutionnelle, Institut Curie, Paris, France and ${ }^{7}$ Département d'Hématologie, Institut Paoli-Calmettes, Marseille, France

Email: Véronique Gelsi-Boyer - gelsiv@marseille.fnclcc.fr; Virginie Trouplin - trouplinv@marseille.fnclcc.fr;

José Adélaïde - adelaidej@marseille.fnclcc.fr; Nicola Aceto - Nicola.Aceto@fmi.ch; Virginie Remy - remyv@marseille.fnclcc.fr; Stephane Pinson - stephane.pinson@chu-lyon.fr; Claude Houdayer - claude.houdayer@curie.net;

Christine Arnoulet - arnouletc@marseille.fnclcc.fr; Danielle Sainty - saintyd@marseille.fnclcc.fr; Mohamed Bentires-Alj - mohamed.bentiresalj@fmi.ch; Sylviane Olschwang - olschwangs@marseille.fnclcc.fr; Norbert Vey - veyn@marseille.fnclcc.fr; MarieJoëlle Mozziconacci - mozziconaccimj@marseille.fnclcc.fr; Daniel Birnbaum* - daniel.birnbaum@inserm.fr; Max Chaffanet - chaffanetm@marseille.fnclcc.fr

* Corresponding author †Equal contributors

Published: 16 October 2008

BMC Cancer 2008, 8:299 doi:10.1 186/1471-2407-8-299
Received: 9 June 2008

Accepted: 16 October 2008

This article is available from: http://www.biomedcentral.com/I47I-2407/8/299

(c) 2008 Gelsi-Boyer et al; licensee BioMed Central Ltd.

This is an Open Access article distributed under the terms of the Creative Commons Attribution License (http://creativecommons.org/licenses/by/2.0), which permits unrestricted use, distribution, and reproduction in any medium, provided the original work is properly cited.

\begin{abstract}
Background: Chronic myelomonocytic leukemia (CMML) is a hematological disease close to, but separate from both myeloproliferative disorders (MPD) and myelodysplastic syndromes and may show either myeloproliferative (MP$\mathrm{CMML}$ ) or myelodysplastic (MD-CMML) features. Not much is known about the molecular biology of this disease.

Methods: We studied a series of 30 CMML samples (I3 MP- and II MD-CMMLs, and 6 acutely transformed cases) from 29 patients by using Agilent high density array-comparative genomic hybridization $(\mathrm{aCGH})$ and sequencing of 12 candidate genes.

Results: Two-thirds of samples did not show any obvious alteration of aCGH profiles. In one-third we observed chromosome abnormalities (e.g. trisomy 8, del20q) and gain or loss of genes (e.g. NFI, RBI and CDK6). RAS mutations were detected in 4 cases (including an uncommon codon I 46 mutation in KRAS) and PTPN II mutations in 3 cases. We detected II RUNXI alterations (9 mutations and 2 rearrangements). The rearrangements were a new, cryptic inversion of chromosomal region $2 \mathrm{I}$ q 1 I-22 leading to break and fusion of RUNXI to USPI6. RAS and RUNXI alterations were not mutually exclusive. RAS pathway mutations occurred in MP-CMMLs ( 46\%) but not in MD-CMMLs. RUNXI alterations (mutations and cryptic rearrangement) occurred in both MP and MD classes $(\sim 38 \%)$.
\end{abstract}

Conclusion: We detected RAS pathway mutations and RUNXI alterations. The latter included a new cryptic USPI6RUNXI fusion. In some samples, two alterations coexisted already at this early chronic stage. 


\section{Background}

Chronic myelomonocytic leukemia (CMML) is a heterogeneous hematopoietic disease currently classified by the WHO organization as an entity close to, but separate from both myeloproliferative disorders (MPD) and myelodysplastic syndromes. CMML is included in the category of MPD/MDS diseases and defined by persistent peripheral monocytosis greater than $1 \times 10^{9} / \mathrm{L}$, fewer than $20 \%$ blasts in the blood or bone marrow (BM), and BM dysplasia in one or more myeloid lineage. Because the blast number is a prognostic factor, CMML is divided in two types: type 1 with fewer than $5 \%$ in blood and $10 \%$ blasts in BM, and type 2 between 5 and 19\% in blood or 10 and 19\% in BM $[1,2]$.

The problem of CMML resides in its classification and in the clinical and/or biological relevance of separating the proliferative and dysplastic presentations. The FAB system has recommended a division of CMML in two classes upon leucocyte count: leucocytosis $<13 \times 10^{9} / \mathrm{L}$ defines CMML as MDS-like (MD-CMML) and leucocytosis $>13 \times$ $10 \% / \mathrm{L}$ as MPD-like (MP-CMML) [2]. The two classes have been variably associated with prognosis and their distinction is a matter of debate [3-7]. This reflects that, except in few imatinib-sensitive cases with PDGFRB alterations, the pathogenesis of CMML is poorly understood. Consequently, the definition and therapy of CMML remain unsatisfactory.

To better understand CMML and improve its classification we have studied the genome of a series of CMML samples by using genome-wide, high-density array-comparative genomic hybridization (aCGH) and DNA sequencing of candidate genes.

\section{Methods}

\section{Patients and samples}

A consecutive series of $30 \mathrm{BM}$ samples were collected from 29 patients including 24 CMMLs and 6 acute transformations of CMML (AT-CMML). Patients were newly diagnosed or were known for hematopoietic disease and the therapeutic impact was evaluated every 3 months. Three patients $(3,52,90)$ had received prior chemotherapy for an independent solid tumor. One had an $11 \mathrm{q}$ inversion and one had a $t(1 ; 3)$. Clinical and biological data of the 30 samples are presented in Additional file 1. Cytology and phenotype were assessed by three specialists (VGB, CA, DS). Nucleic acids extraction was done as described [8]. Gene expression profiles for the cases with available RNA have been reported [8]. The patients all signed an informed consent. The project and collection of samples were reviewed by the independent scientific review board of the Paoli-Calmettes Institute (COS), in accordance with current regulations and ethical concerns.

\section{Array comparative genomic hybridization (aCGH)}

Genomic imbalances were analyzed by aCGH using $244 \mathrm{~K}$ CGH Microarrays (Hu-244A, Agilent Technologies, Massy, France) as previously described $[9,10]$. The resolution is up to $6 \mathrm{~kb}$. Scanning was done with Agilent Autofocus Dynamic Scanner (G2565BA, Agilent Technologies). Data analysis was made as previously described [10,11] and visualized with CGH Analytics 3.4 software (Agilent Technologies). Extraction data ( $\log _{2}$ ratio) was done with CGH analytics while normalized and filtered $\log _{2}$ ratio were obtained from $<<$ Feature extraction $\gg$ software (Agilent Technologies). Copy number changes were characterized as reported $[9,10]$.

The RUNX1 gene map established within $\mathrm{Mb}$ scale was extracted from the build 36.1 from NCBI (March 2006 version) while its sequence (Ensembl Transcript ID ENST00000300305) was extracted from Ensembl database http://www.ensembl.org/Homo sapiens/, which is based on the Ensembl release 48 - Dec 2007 assembly of the human genome. Genomic profile was established with CGH analytics ${ }^{\circledR}$ software (Agilent Technologies), from centromere to telomere, within the genomic intervals [28.0-30.5 Mb] and [33.8-36.3 Mb] of the short arm of the chromosome 21 (hg17 human genome mapping; build 35 from NCBI, May 2004 version).

\section{DNA sequencing}

Somatic mutations of BRAF, JAK2, HRAS, KRAS, NRAS, NF1, RAF1, RB1, RUNX1, SOS1, SPRED1 and STK11 genes were searched by sequencing exons and consensus splicing sites after PCR amplification of genomic DNA (Additional file 2). Most PCR amplifications were done in a total volume of $25 \mu \mathrm{l}$ PCR mix containing at least $10 \mathrm{ng}$ template DNA, Taq buffer, $200 \mu \mathrm{mol}$ of each deoxynucleotide triphosphate, $20 \mathrm{pmol}$ of each primer and 1 unit of Hot Star Taq (Qiagen). PCR amplification conditions were as follows: $95^{\circ} \mathrm{C} 10 \mathrm{~min} ; 95^{\circ} \mathrm{C} 30 \mathrm{sec}$, variable temperature $30 \mathrm{sec}, 72^{\circ} \mathrm{C} 45 \mathrm{sec}$ for 30 cycles; $72^{\circ} \mathrm{C} 10 \mathrm{~min}$. PCR products were purified using Millipore plate MSNU030.

Two microliters of the purified PCR products were used for sequencing using the Big Dye terminator v1.1 kit (Applied Biosystems). After G50 purification, sequences were loaded on an ABI 3130XL automat (Applied Biosystems). The sequence data files were analyzed using the SeqScape software (Additional file 2) and all mutations were confirmed on an independent PCR product.

\section{PCR detection of RUNXI alterations}

The USP16-RUNX1 gene fusion was detected by using nested PCR amplification of retrotranscribed mRNA (RTPCR) from BM cells of the patients as previously described [12]. Wild-type and fusion transcripts were amplified 
using RUNX1 and USP16 primer sequences (Additional file 3). PCR products were visualized on agarose gel with ethidium bromide, and sequenced.

\section{Results}

Three types of aCGH profiles in CMML

Using genome-wide, high-density arrays we established the aCGH profiles of 30 samples from 29 patients, comprising 24 CMMLs and 6 AT-CMMLs. Examples of profiles are shown in Figure 1 and results are summarized in Table 1 . Three main types of profiles were observed. Type 1 profiles showed gains or losses visible on the karyotype and affecting large regions of the genome, such as trisomy 8 (10\%: cases 5, 12 and 88 ), deletions of part of the $20 \mathrm{q}$ arm (10\%: cases 3, 74, and 96), or deletion (case 106) or complex rearrangements of chromosome 7 (case 3). Type 2 profiles showed rare and limited gains or losses that affected few or single genes such as deletions encompassing $N F 1$ at $17 \mathrm{q} 11$ (case 80 ), RB1 at $13 \mathrm{q} 14$ (case 74), RUNX1 at $21 \mathrm{q} 21$ (case 88 ), CALN1 at 7q11 (case 12), amplification of $7 \mathrm{q} 21$ including the CDK6 gene (case 3) or a series of short deletions on the $3 \mathrm{q}$ arm (case 1). A surprising deletion of the MYC locus was observed in case 106. The type 3 profile was said "normal-like" since no obvious alteration was detected. It occurred in two-thirds of the cases.

\section{Mutations of RAS and RUNXI genes}

We analyzed the sequences of the three RAS genes. No mutation of HRAS was found. NRAS mutations were found in cases 12 and 78, and KRAS mutations in cases 79 and 89 (Table 1). One of these mutations affected codon
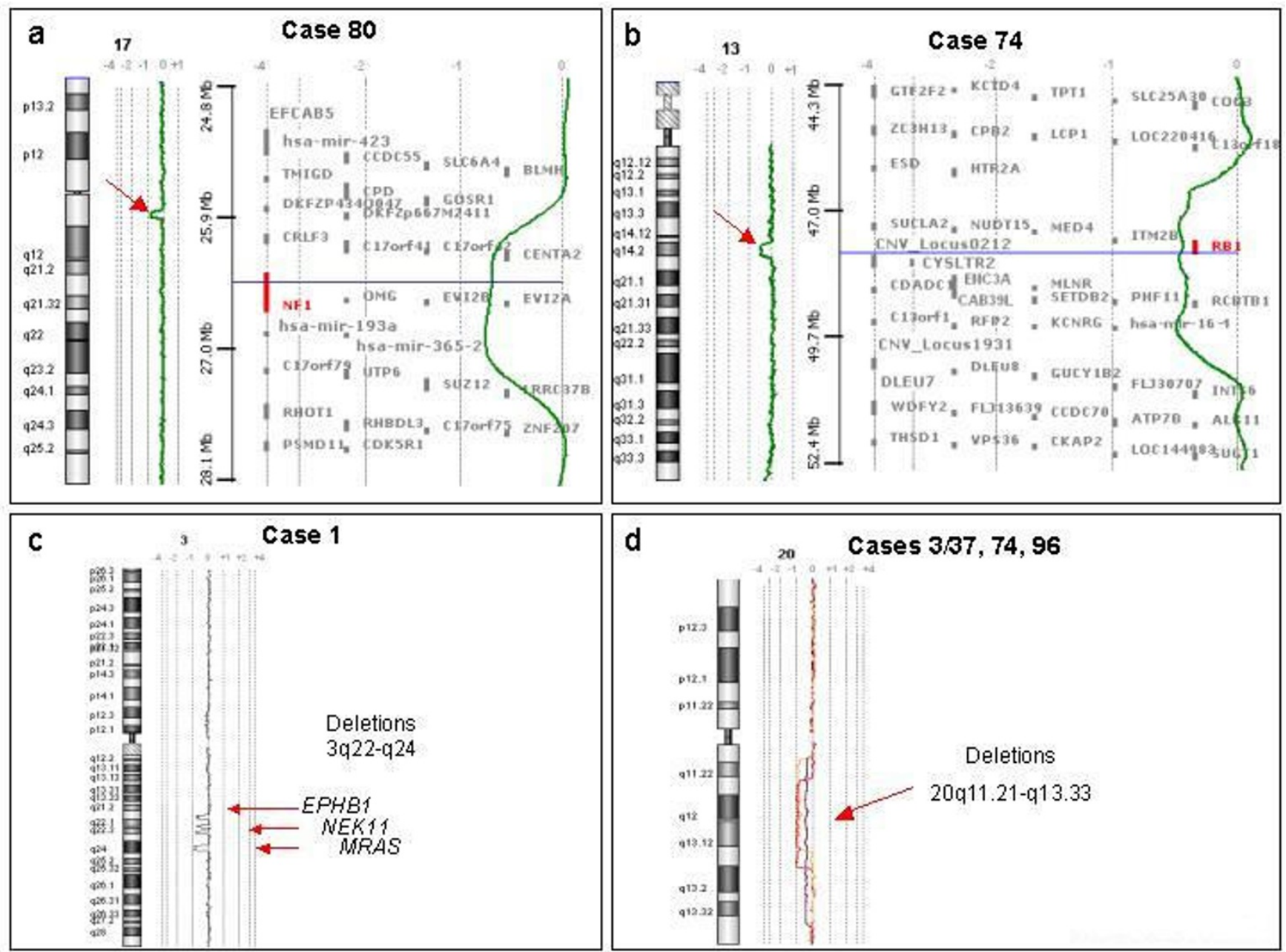

\section{Figure I}

Examples of aCGH profiles. A: aCGH profile of chromosome 17 in case 80. Red arrow shows deletion including NFI. B: aCGH profile of chromosome 13 in case 74 showing $R B /$ deletion. For a and b, a zoom of the region is shown to the right of the profiles. C: aCGH profile of chromosome 3 in case I showing a series of deletions at 3q. D: aCGH profiles of chromosome 20 in cases 3, 37, 74 and 96 ( 3 and 37 are from the same patient). 
Table I: Molecular features of the 30 studied CMML

\begin{tabular}{|c|c|c|c|c|c|c|c|c|c|}
\hline No & Diagnosis & Karyotype & Array-CGH & H, K, NRAS & NFI & PTPNII E3, I3 & RUNXI & SOSI E7-II & $\begin{array}{l}\text { USPI 6-RUNXI } \\
\text { rearrangement }\end{array}$ \\
\hline I & CMML 2 & $46, X Y[20]$ & $\begin{array}{c}\text { 3q22-24 losses } \\
\text { (EPHBI, NEKII, } \\
\text { MRAS...) }\end{array}$ & no & nd & p.Asp6 I Tyr & p.Pro425Leu & p.Leu569 Val & nd \\
\hline 5 & CMML 2 & $47, X X,+8[20]$ & Tri 8 & no & nd & p.Ala72Thr & Splicing defect & no & nd \\
\hline 6 & CMML 2 & $46, X Y[20]$ & $\begin{array}{c}3 p 23 \text { loss } \\
\text { (GLBI, CRTAP) }\end{array}$ & no & nd & no & p.Arg166X & no & nd \\
\hline 7 & CMML I & $46, X X[20]$ & normal-like & no & nd & no & no & no & nd \\
\hline 12 & CMML I & $47, X X,+8[20]$ & $\begin{array}{l}\text { Tri 8, 7ql I loss } \\
\text { (CALNI) }\end{array}$ & N-p.Gly I 2Asp & nd & no & $\begin{array}{c}\text { p.Tyr377LeufsX2 } \\
23\end{array}$ & no & nd \\
\hline 13 & CMML I & 46, XY [20] & normal-like & no & nd & no & no & no & nd \\
\hline 15 & CMML I & $46, X Y[20]$ & normal-like & no & nd & no & p.Gly50GInfsX4 & no & nd \\
\hline 51 & CMML I & $46, X Y[20]$ & normal-like & no & nd & no & no & no & no \\
\hline 72 & CMMLI & $46, X Y[20]$ & $7 p 21$ gain $(A H R)$ & no & nd & no & no & no & no \\
\hline 78 & CMML I & $45, X,-X ? c[20]$ & $X$ loss & N-p.Gly | 2Asp & nd & no & no & no & no \\
\hline 79 & CMML I & $46, X Y[20]$ & normal-like & K- p.Gly I 2Ser & p. $=$ & no & no & no & no \\
\hline 2 & CMML I & $46, X Y[20]$ & normal-like & nd & nd & no & no & no & nd \\
\hline 95 & CMML I & $46, X X[20]$ & normal-like & no & nd & no & no & no & no \\
\hline 75 & CMML I & $46, X Y[20]$ & normal-like & no & nd & no & no & no & no \\
\hline 89 & CMML I & $46, X Y[20]$ & normal-like & K- p.Ala I 46Val & nd & no & no & no & no \\
\hline 3 & CMML I & $\begin{array}{c}\text { 46, XY, } \\
\operatorname{del}(20)(q|\mathrm{q}| 3)[20]\end{array}$ & nd & no & nd & no & p.Arg 166X & no & nd \\
\hline 38 & CMML I & $46, X Y[20]$ & normal-like & no & nd & no & no & no & no \\
\hline 52 & CMML 2 & $\begin{array}{c}\text { 46, XX, } \\
\operatorname{inv}(I I)(p 15 q 22)[20]\end{array}$ & normal-like & no & nd & no & no & no & no \\
\hline
\end{tabular}


Table I: Molecular features of the 30 studied CMML (Continued)

\begin{tabular}{|c|c|c|c|c|c|c|c|c|c|}
\hline 90 & CMML 2 & $\begin{array}{c}46, X X \\
t(1 ; 3)(p 36 ; q 2 I)[20]\end{array}$ & normal-like & no & nd & no & p. $=$ & no & no \\
\hline 8 & CMML 2 & $46, X Y[20]$ & normal-like & no & nd & no & no & no & nd \\
\hline 25 & CMML I & $46, X Y[20]$ & normal-like & no & nd & no & p.Leu56Ser & no & nd \\
\hline 63 & CMML 2 & $46, X Y[20]$ & normal-like & no & nd & no & no & no & no \\
\hline 74 & CMML I & $\begin{array}{c}\text { 46, XY, } \\
\operatorname{del}(20)(q|| q \mid 3)[20]\end{array}$ & $\begin{array}{l}20 q||-q \mid 3 \text { loss, } \\
|3 q| 4 \text { loss (RBI) }\end{array}$ & no & nd & no & no & no & no \\
\hline 87 & CMML I & $46, X Y[20]$ & normal-like & no & nd & no & p.Arg320X & no & no \\
\hline 34 & AT-CMML & $46, X X[20]$ & normal-like & no & nd & p.GIn5 I OHis & no & no & $\begin{array}{l}\text { USPI6_EI- } \\
\text { RUNXI_E7 }\end{array}$ \\
\hline 37 & AT-CMML & $\begin{array}{c}\text { 46, XY, } \\
\operatorname{del}(20)(q|| q \mid 3) \\
{[13] / 46, \text { idem, }-7,} \\
\text { +mar [5]/46, idem, } \\
\operatorname{del}(\mid 2)(p|I-| 2 p \mid 3) \\
{[5]}\end{array}$ & 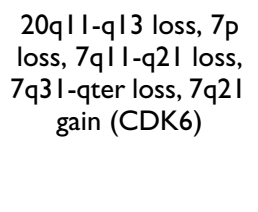 & no & nd & no & p.Arg166X & nd & No \\
\hline 80 & AT-CMML & $\begin{array}{c}46, X Y \\
\operatorname{del}(9)(q 2 I q 34)[19] / \\
46, X Y[20]\end{array}$ & $\begin{array}{c}9 q 21.11-q 22.33 \text { loss, } \\
17 q 1 \mid \text { loss (NFI) }\end{array}$ & nd & no & no & no & no & No \\
\hline 88 & AT-CMML & $\begin{array}{c}47, \mathrm{XY},+8[\mathrm{II}] / 46 \\
\mathrm{XY}[9]\end{array}$ & $\begin{array}{l}\text { Tri 8, } 2 \text { I q2 I losses } \\
(\text { RUNXI) }\end{array}$ & no & nd & no & no & no & $\begin{array}{l}\text { USPI6_EI- } \\
\text { RUNXI_E5 }\end{array}$ \\
\hline 96 & AT-CMML & $\begin{array}{c}46, X Y \\
\operatorname{del}(20)(q|| q \mid 3), \\
+\operatorname{mar}[18]\end{array}$ & $20 q|I-q| 3$ loss & no & nd & nd & no & no & no \\
\hline 106 & AT-CMML & $46, X Y[20]$ & $\begin{array}{c}7 \text { loss, 8q24 loss } \\
\text { (MYC) }\end{array}$ & no & nd & nd & no & no & no \\
\hline
\end{tabular}

CMMLs are classified by a double line as in Additional file I.

CMML: chronic myelomonocytic leukemia.

AT-CMML: acute transformation of CMML in acute myeloid leukemia (all M4 FAB type).

Samples 3 and 37 are from the same patient.

In bold: myeloproliferative CMML.

nd: not done.

E: exon.

Tri: trisomy. 
146 in coding exon 3, a rare type of RAS mutation that has been found in $4 \%$ colorectal cancers and two hematopoietic cell lines [13]. For patient 79 we determined that the mutation was present in a heterozygous state in the CD34-purified fraction of the BM cells, in the polynuclear neutrophils, monocytes and B lymphocytes but absent in the T cells (data not shown).

We examined the sequence of exons 3 and 13 of the PTPN11 gene. Mutations were found in three cases. No mutation was found in exon 7 of RAF1, which is a hotspot for mutations in Noonan syndrome (NS) [14,15]. SOS1 and $B R A F$ were also sequenced in their most frequently mutated regions (exons 7-11 and kinase-encoding exons, respectively). One mutation was identified in SOS1 in a region involved in NS [16], none in BRAF. No mutation was found in SPRED1 [17].

The NF1 gene was analyzed for mutations in cases 79 and 80. A silent, so far unreported point mutation (c.2178G>C) was found in case 79 (Table 1). The deletion of an RB1 allele was confirmed by sequencing in case 74 and the remaining $R B 1$ allele was normal. There was no JAK2 p.Val617Phe mutant in our panel of CMML cases.

Mutations were found in the RUNX1 gene in 10 patients $(30 \%)$. Mutation in case 90 is predicted to induce neither amino acid change nor splicing effect and thus was not considered as functionally deleterious. The nine other nucleotide variations would result in truncated or mutant proteins. RUNX1 mutations are described in Figures 2 and 3.

Finally, no mutation was found in the STK11/LKB1 and SYK kinase genes.

\section{A novel, cryptic rearrangement of RUNXI following $\operatorname{inv}(2$ Iq)}

The aCGH profile of case 88 showed two losses at $21 \mathrm{q} 21.3$ and q22.12 of about $1.04 \mathrm{Mb}$ and $0.82 \mathrm{Mb}$, respectively (Figure 4A). They spanned the 3' part of USP16, including exons 2 to $19, C C T 8, B A C H 1$ and GRIK1 as well as the 5' part of RUNX1 (including exons 1 to 4 ), respectively. We hypothesized that such a peculiar pattern could be due to a cryptic inv(21)(q21q22) associated with a microdeletion at one of the breakpoints. Given the features and orientation of the various potentially-involved genes, we surmise that a fusion could involve RUNX1 and USP16 (encoding a de-ubiquitinating enzyme). This was confirmed by nested PCR amplification of reverse-transcribed RNA from the patient's BM cells, which detected a $245 \mathrm{bp}$ long USP16-RUNX1 transcript (Figure 4B). No reciprocal transcript was detected. Sequence analysis showed that the result of the inversion/fusion generated a chimeric USP16-RUNX1 transcript. The break/fusion was not present in the germline since we did not find the USP16RUNX1 transcript in buccal smear cells of the patient. The USP16-RUNX1 gene fuses exon 1 of USP16 to exon 5 of RUNX1 thus not preserving the canonical ATG codons. The chimeric transcript exhibited several stop codons in its $5^{\prime}$ part but the presence of multiple ATG codons through exons 5 to 7 of RUNX1 sequence could be used as new start codons and generate putative truncated RUNX1 proteins. A similar USP16-RUNX1 fusion (without microdeletion) was found in CMML 34 (Table 1). In the two cases, the USP16-RUNX1 fusion transcripts did not have an open reading frame using the canonical start codons of USP16 or RUNX1 (Figure 5). According to the SMART program http://smart.embl-heidelberg.de/, functional domains (i.e. RUNT and RUNXI [for RUNX Inhibitor domain], as defined by PFAM accession numbers PF00853 and PF08504, respectively) should disappear in such putative truncated RUNX1 proteins. RUNT and RUNXI domains are encoded mainly by exons 3 to 5 and exon 8 , respectively (Figure 3 ). The partial conservation of RUNX1 transcript sequence (exons 5 to 8 ) and a new folding could explain conformational changes and the absence of RUNT and RUNXI domains.

In total, RUNX1 was altered by mutation (9) or break (2) in 11 patients (8 CMMLs and 3 AT-CMMLs) (Table 2).

Unsurprisingly, the $11 \mathrm{q}$ inversion in case 52 and the balanced $\mathrm{t}(1 ; 3)(\mathrm{p} 36 ; \mathrm{q} 21)$ in case 90 escaped aCGH detection. The $11 \mathrm{q}$ inversion was probably a case of NUP98DDX10 fusion [18] and the $\mathrm{t}(1 ; 3)$ a case of PRDM16/ MEL1-RPN1 fusion [19].

\section{Different alterations in MP- and MD-CMML}

Excluding the 6 AT-CMMLs, RAS and PTPN11 mutations were found in 6 of the 13 MP-CMMLs ( 46\%) whereas no such mutation was found in the $11 \mathrm{MD}$-CMMLs (Table 2). In contrast, RUNX1 mutations occurred in both MP- (5 cases) or MD-CMML (3 cases).

\section{Discussion}

We have established the first high resolution genome profiling of CMML and found a high frequency of RAS and RUNX gene alterations.

\section{CMML and the RAS pathway}

In the majority of cases the aCGH profiles did not show any alteration. This suggests that rearrangements and copy number aberrations are not prominent in CMML and that aCGH is only in part suited for obtaining further insight into the pathogenesis of this disease. However, in a small proportion of the cases aCGH was informative, pointing to known tumor suppressor genes such as NF1 and RB1. However, neither gene was mutated in the remaining allele. Deletion of NF1 was particularly interesting since it 
Case 89 KRAS p.Ala146Val

Case 1 PTPN11 p.Asp61TyT

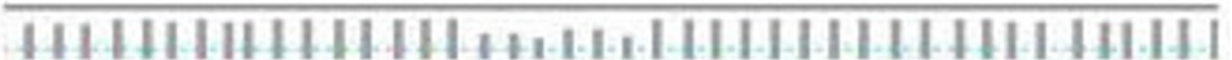
CTT TTATTOAACATCAGCAAAGACAAGACAGGTAAGTAAC, $270 \quad 280$
290

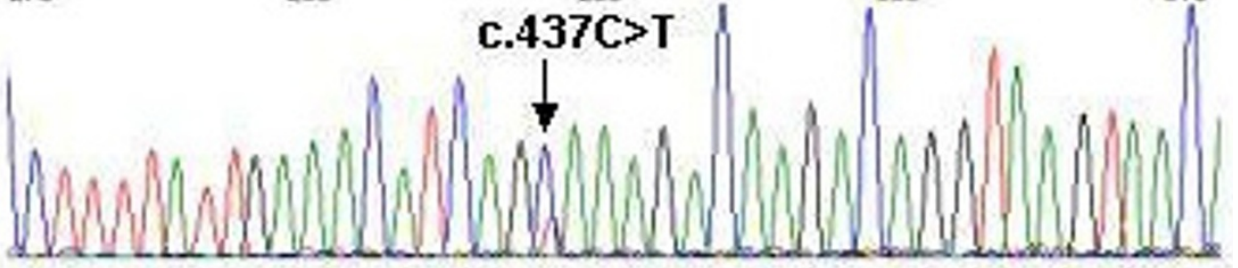

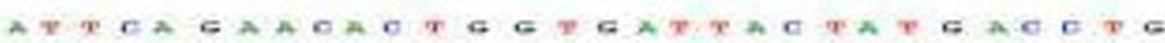

c.561G $>\mathrm{T}$

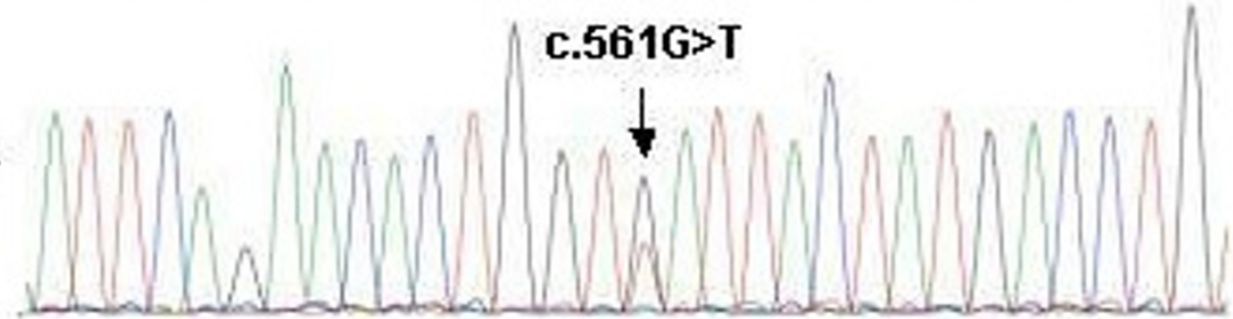

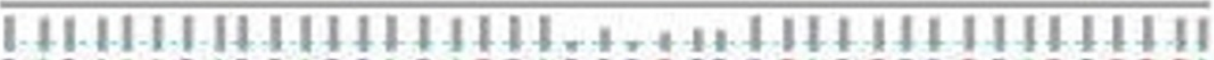

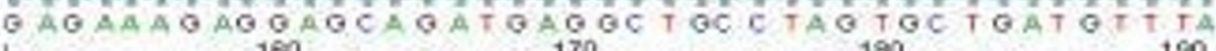

Case 1

SOS1 p.Leu569Val

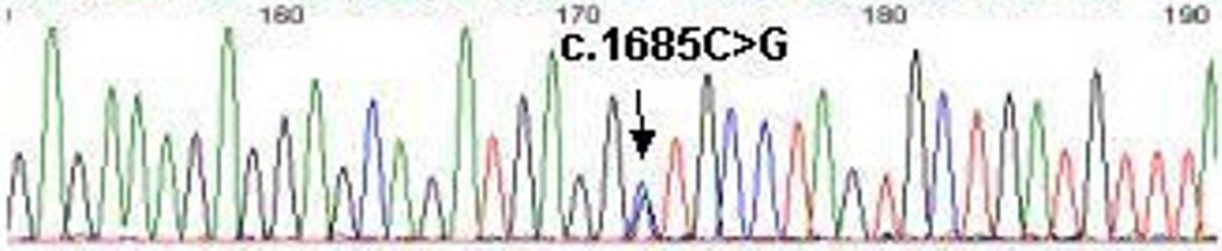

Case 6 RUNX1 p.Arg166X
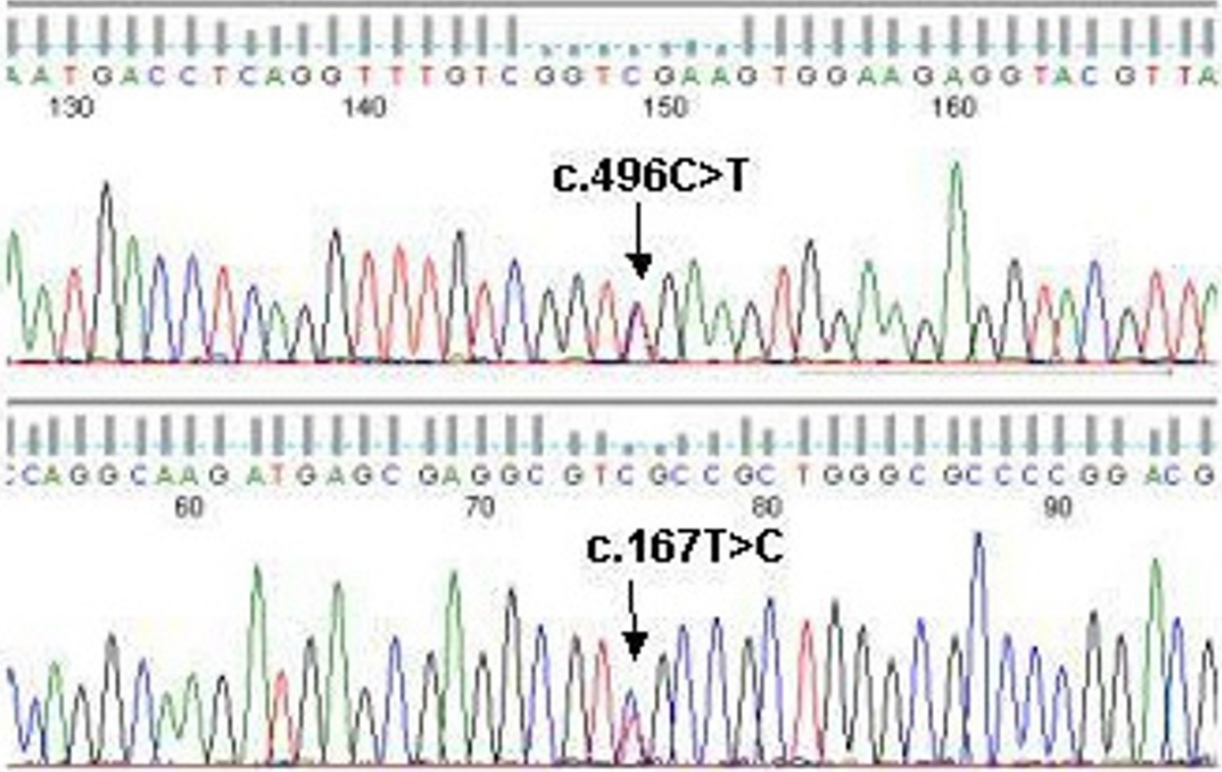

Case 25 RUNX1 p.Leu56Ser

Mutation of RAS, PTPNII and RUNXI genes in CMML. Examples of mutations in candidate genes. From top to bottom, sequence of the mutated KRAS, PTPNII, SOSI and RUNXI alleles, demonstrating base change in the forward sequence at the position indicated by an arrow. The corresponding sequence is shown above. Primers and conditions used are described in additional file 2 . 


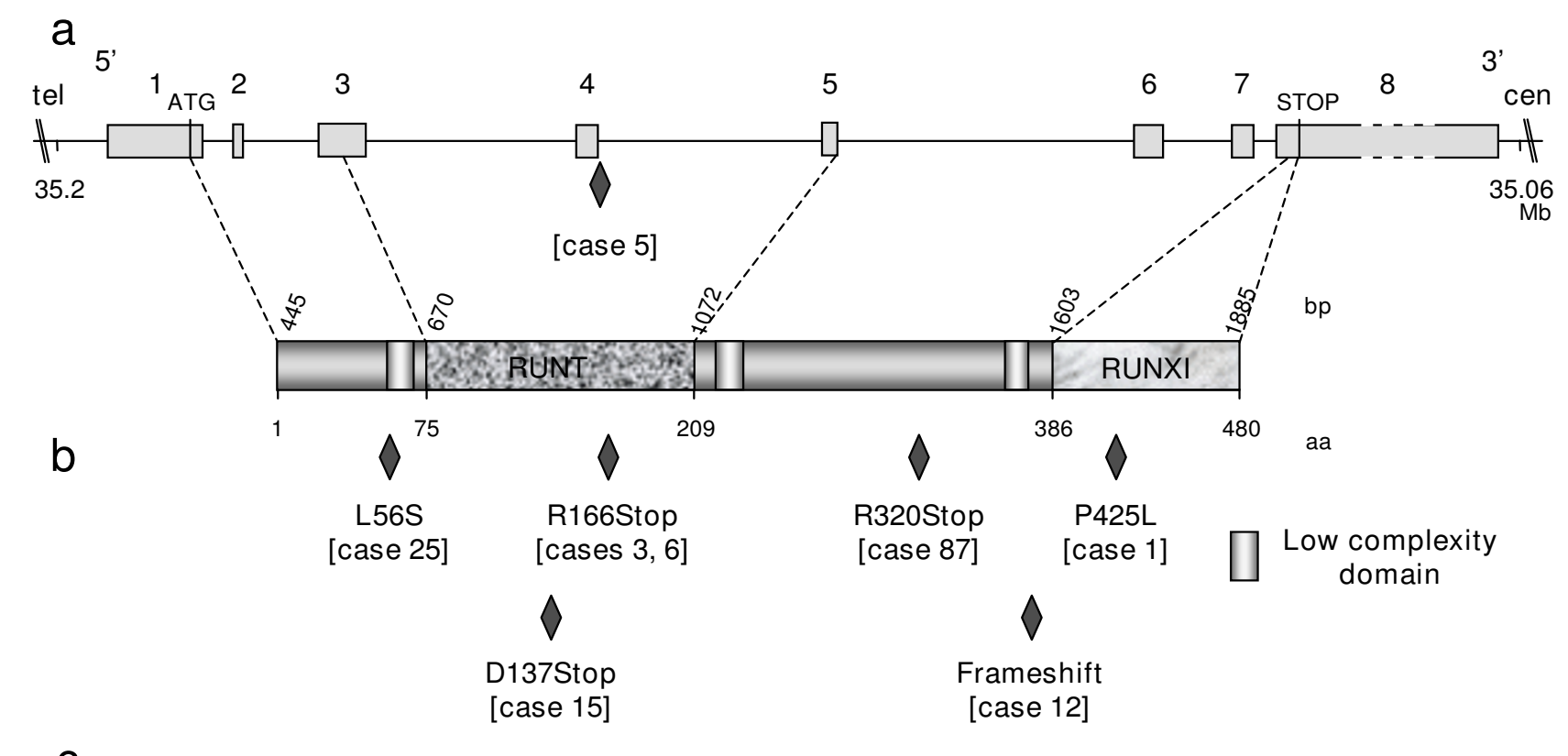

C

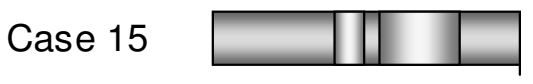

136
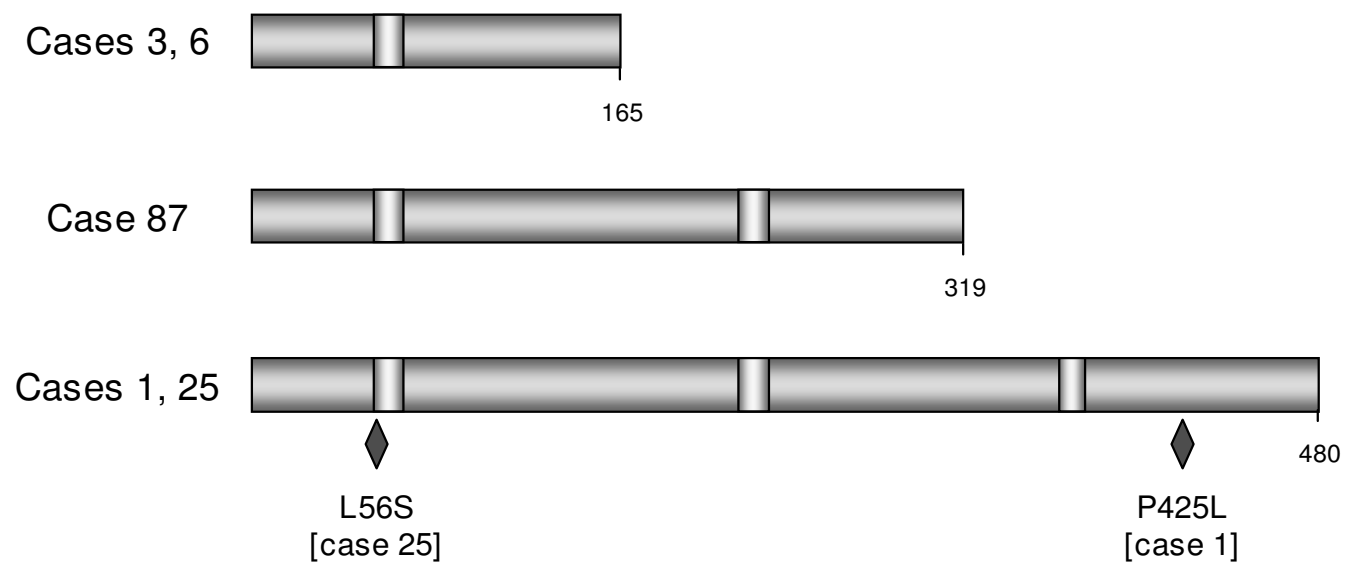

\begin{tabular}{|l|l|l|l|l|l|l|l|l|l|}
\hline Case 12 & & & & & & & & & \\
\hline
\end{tabular}

\section{Figure 3}

Characterization of RUNXI mutations in CMML patients. A: Genomic organization of RUNXI gene at 21 q22.12 and RUNXI protein. Functional (i.e. RUNT and RUNXI [for RUNX Inhibitor domain], as defined by PFAM accession numbers PF00853 and PF08504, respectively) and motifs of the RUNXI protein were positioned according to the SMART program http://smart.embl-heidelberg.de/. Nucleotide (cDNA level) and deduced aminoacid sequences of the RUNXI protein are positioned above and below the corresponding protein, respectively. The genomic RUNXI sequence of CMML 5 exhibited a mutation in the consensus splicing sequence of intron 3. B: Mutations of RUNXI. All mutations but one introduced an aberrant stop codon (cases 3, 6, I2, I5 and 87). Two missense mutations (cases I and 25) were also observed. The mutations are located with respect to the modified aminoacid of the RUNXI protein. C: Representation of putative mutated RUNXI proteins. According to the SMART program, all putative modified proteins have lost their RUNT and RUNXI domains. 


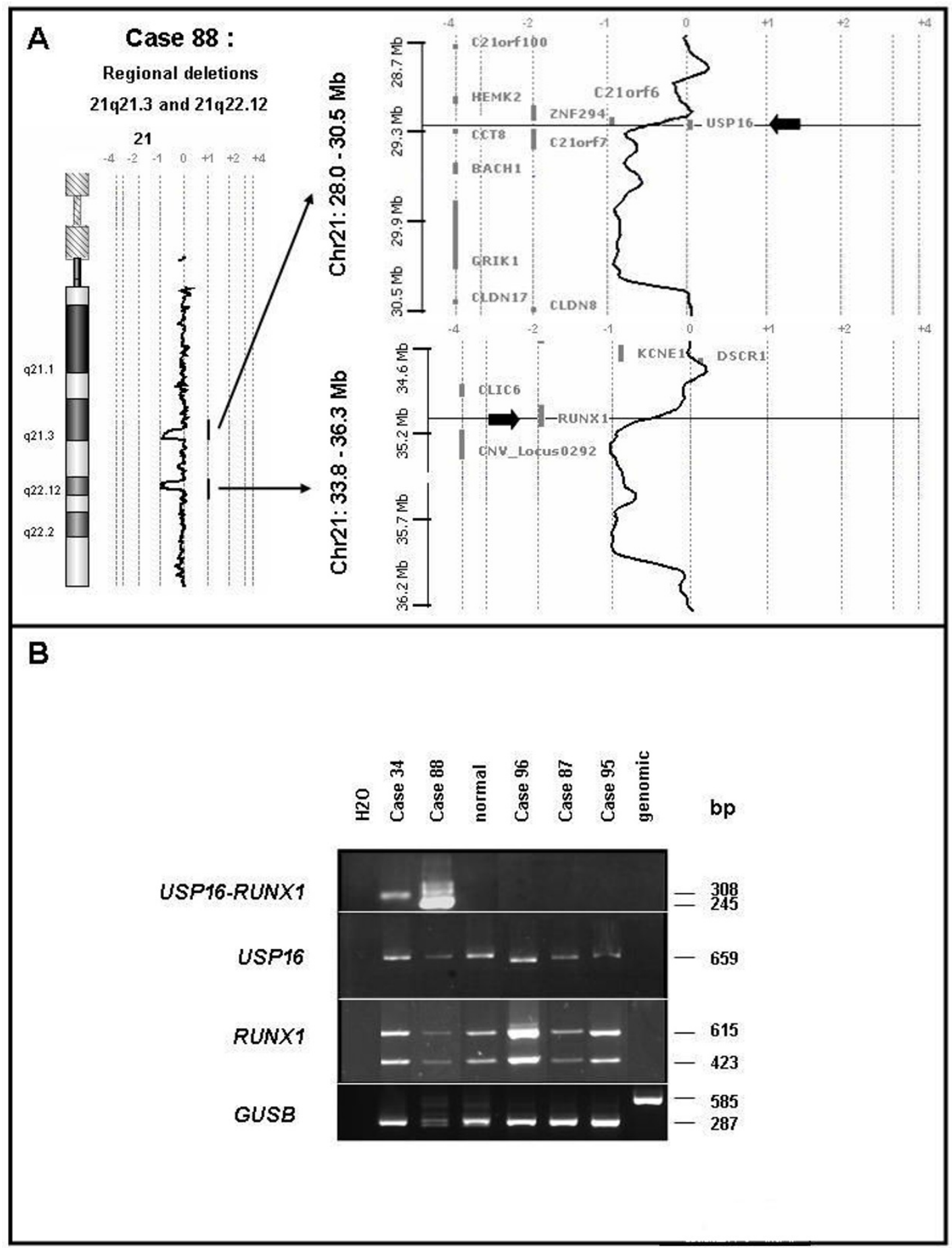

Figure 4

Genomic rearrangements involve USPI6 and RUNXI genes in CMML patients. A: CMML 88 aCGH profile of chromosome 21 shows regional deletions in 21 q21.3 and 21 q22. I2. Arrows point to USPI 6 and RUNXI genes targeted by transition profiles located in these respective regions. This suggests that potential gene breaks involve USPI6 and RUNXI. B: PCR characterization of USPI6-RUNXI fusions in CMML. USPI6, RUNXI and USPI6-RUNXI transcripts were detected in the BM cells of the patients. The size of amplified products is shown on the right. The existence of alternatively spliced RUNXI products could explain the various sizes observed for USPI6-RUNXI and RUNXI transcripts. CDNA of normal lymphocytes were used as control. Primers specific for the human GUSB transcript were used for control of the RT-PCR quality control. 


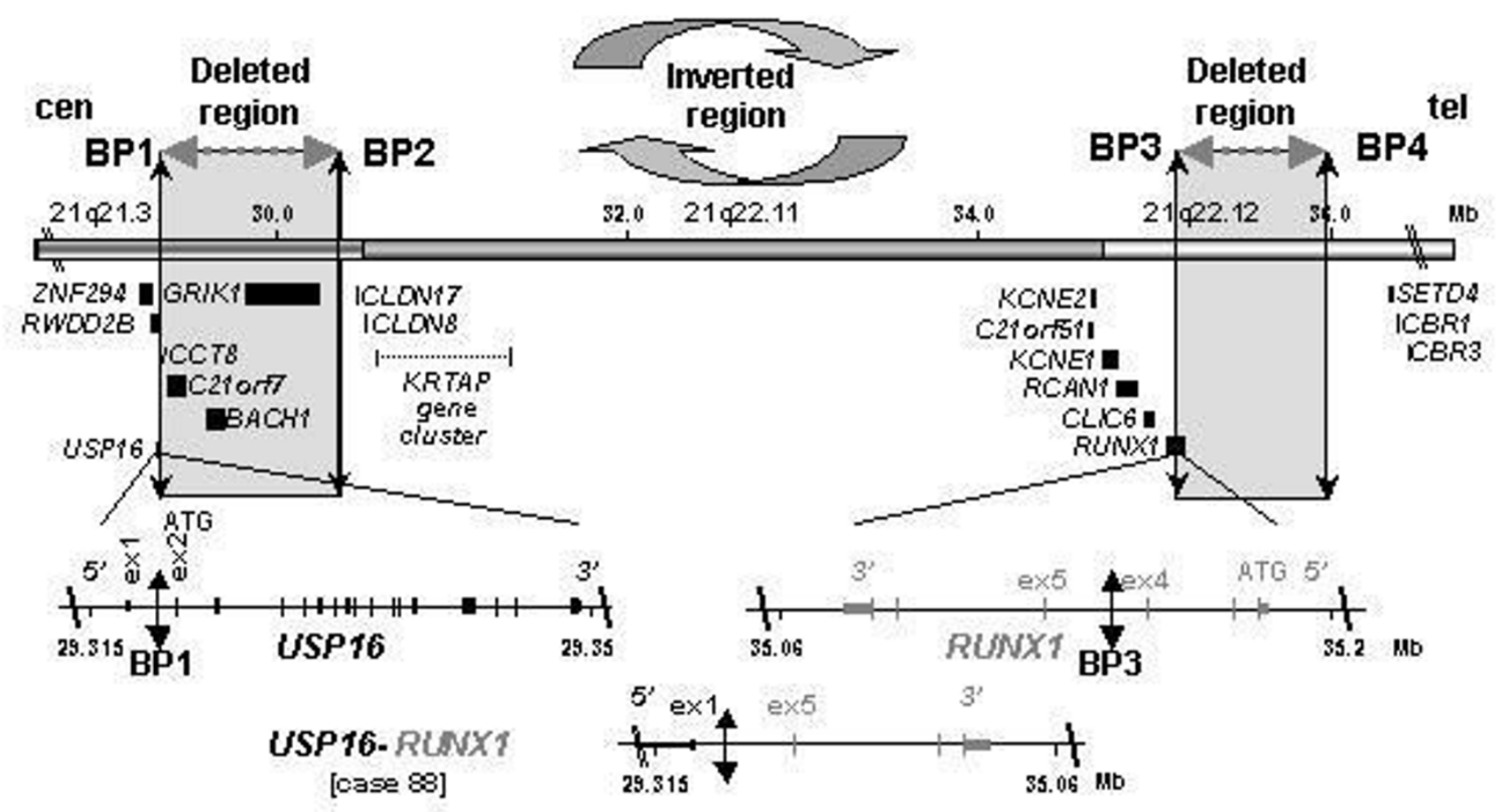

Figure 5

USPI6-RUNXI rearrangement in CMML 88. Organization of chromosomal region $21 \mathrm{q} 21.3-\mathrm{q} 22.12$ with the location of the breakpoints (BP) and deleted regions from centromere (cen) to telomere (tel). Mb scale of the corresponding $2 \mathrm{Iq} 2 \mathrm{I} .3$, 2 Iq22. II and 2 Iq22. 12 regions corresponds to cytogenetic bands. Only genes flanking affected regions are reported on the figure. Breakpoints BPI and BP3 targeting USPI6 and RUNXI are associated with deletions defined by intervals [BPI-BP2] and [BP3-BP4]. The USPI6-RUNXI gene fusion is explained by the inversion of the central interval [BP2-BP3]. ATG codons are in exon 2 (ex 2) and exon I (ex I) of USPI 6 and RUNXI, respectively.

led us to suspect an alteration of the RAS pathway and a similarity with juvenile myelomonocytic leukemia (JMML). JMML is a chronic myelomonocytic disease that occurs early in life, often on a genetic background of NS, and neurofibromatosis type 1. [20-22]. Half of NS are caused by germline mutations in the PTPN11 gene, which encodes a RAS pathway-regulating phosphatase. Germ- line mutations in KRAS, SOS1, RAF1, BRAF and other genes of the RAS pathway account for the other NS cases $[14,15,20,23]$. Syndromes caused by a hyperactivation of the RAS pathway also include Costello, cardio-facio-cutaneous (CFC), hereditary gingival fibromatosis and LEOPARD syndromes, and are collectively called neuro-cardiofacial-cutaneous (NCFC) syndromes [24].

Table 2: Summary of results.

\begin{tabular}{|c|c|c|c|c|c|c|}
\hline & $\begin{array}{l}\text { All CMMLs } \\
(\mathbf{N}=\mathbf{3 0})\end{array}$ & $\begin{array}{c}\text { All non AT-CMMLs } \\
(N=24)\end{array}$ & $\begin{array}{l}\text { MP-CMMLs } \\
(N=13)\end{array}$ & $\begin{array}{c}\text { MD-CMMLs } \\
(\mathrm{N}=\mid \mathrm{I})\end{array}$ & $\begin{array}{l}\text { AT-CMMLs } \\
(N=6)\end{array}$ & $\begin{array}{c}\text { RUNXI } \\
\text { alteration }\end{array}$ \\
\hline Normal-like & 17 & 16 & 6 & 10 & 1 & 7 \\
\hline Trisomy 8 & 3 & 2 & 2 & 0 & I & 3 \\
\hline Del20q & 4 & 2 & I & I & 2 & 3 \\
\hline RAS pathway mutation & 7 & 6 & 6 & 0 & I & 4 \\
\hline RUNXI alteration & 11 & 8 & 5 & 3 & 3 & 11 \\
\hline RUNXI mutation & 9 & 8 & 5 & 3 & I & 9 \\
\hline USPI6-RUNXI & 2 & 0 & 0 & 0 & 2 & 2 \\
\hline
\end{tabular}

RAS pathway mutations include point mutations in KRAS, NRAS and PTPNII. RUNXI alterations include RUNXI mutations and breaks. Two cases (I AT and I non-AT) are from the same patient. 
We thus sequenced genes coding for proteins involved in the RAS signaling pathway and a RAS mutation was found in four cases ( $14 \%$ ), including a codon 146 mutation in KRAS. In a recent study of CMML, mutations of KRAS and NRAS genes were found in 9 patients out of 32 [25]; two of the six KRAS mutations were in codon 146. It is thus possible that mutation at this site is more frequent than expected, at least in hematopoietic diseases. Germline mutations of KRAS have been found in NCFC syndromes $[24,26]$. Germline RAS mutations induce precursor lesions and especially myeloproliferative disorders that resemble JMML and CMML [27-29]. In patient 79 the KRAS p.Gly12Ser substitution was present in the myeloid and B lymphoid lineages but not in T cells. We found mutations of PTPN11 exon 3 in 2 cases and exon 13 in one case (other exons were not screened). Somatic mutations of PTPN11 occur in approximately one-third of JMMLs but are less frequent in CMMLs [30,31]. Our combined results indicate that mutations in the RAS pathway occurred in at least one-fourth of CMML cases. No HRAS mutation was detected, in agreement with the absence of hematological manifestations in HRAS-linked Costello syndrome. CMML (at least MP-CMML) shares molecular features with JMML, i.e. similar non-specific alterations of chromosomes 7, 8 and 20, gene fusions [32] and alterations of genes suggesting activation of the RAS pathway. Inhibitors of the RAS pathway might be efficient in treating CMML $[33,34]$.

\section{CMML and RUNXI alterations}

Two cases showed a break in RUNX1 due to an inversion of chromosomal region 21q21-22. RUNX1 encodes the DNA-binding, alpha subunit of the core binding factor (CBF) and is viewed as a tumor suppressor gene whose haplo-insufficiency or dominant-negative mutations play a role in leukemogenesis [35,36]. The gene is also frequently involved in translocations, with more than 15 different partners $[37,38]$. CBFB is the $\beta$ subunit of the heterodimeric $\mathrm{CBF}$ factor. $\mathrm{CBF}$ regulates hematopoietic stem cell behavior and is essential for definitive hematopoiesis [39]. We show here that RUNX1, already known as a major translocation breakpoint, may even be more frequently altered than thought. Indeed, the $21 \mathrm{q}$ inversion is not detectable by karyotyping and, if not for the interstitial microdeletion, would not be detected by aCGH.

RUNX1 mutations were frequent in our series of CMML. In contrast to RAS pathway mutations, mutations of RUNX1 have been reported unfrequently in CMML and JMML, perhaps due to the experimental approach [40]. Overall, we found alterations of RUNX1 in roughly half of the non-acutely transformed cases. They resulted in various truncated or aberrant proteins that could act as dominant-negative isoforms or result in haplo-insufficiency.
Case 12 shows a deletion of CALN1, encoding calneuron 1 , a calmodulin-like protein. Calmodulin regulates calcineurin, which is recruited by RUNX1 to regulate granulocyte-macrophage colony-stimulating factor [41]. Finally, CDK6, whose gene is amplified in case 3, inhibits RUNX1 activity [42]. Noticeably, amplification of CDK6 has been recently described in lymphoma [43]. Thus, alteration of RUNX1 function may occur frequently and by different mechanisms in CMML.

\section{Other alterations}

Patient 52 had been treated for breast cancer and the CMML may be due to a therapy-related pericentric inversion of chromosome 11 with NUP98-DDX10 fusion. CMML 90 may be due to a fusion between PDRM16 (EVI1-like) and RPN1. Such fusion is found in MDS and AML-M4 [44].

Not surprisingly, CMML shares molecular features with MDS and AML, especially therapy-related diseases, including loss or partial deletions of chromosome 7, rearrangement of the RUNX1 gene, mutations of RAS and PTPN11 [45].

\section{Cooperative and exclusive alterations}

RAS pathway mutations and RUNX1 alterations were not mutually exclusive. RAS mutations, PTPN11 mutations and NF1 deletion were mutually exclusive. However, in case 1, mutations of PTPN11 and SOS1 were found. The two mutations could synergize but the SOS1 mutation has never been reported and its functional relevance remains unknown.

\section{Myeloproliferative vs myelodysplastic CMML}

Six RAS pathway alterations were found in 13 MP-CMMLs but none in 11 MD-CMMLs ( $\mathrm{p}=0.016$, Fisher exact test). An even higher proportion of MP-CMMLs may be due to mutation in the RAS pathway because other cases could be due to mutations occurring elsewhere in these genes or in other genes of the RAS pathway. This suggests that MPand MD-CMMLs could develop along two different oncogenic pathways, specific of two distinct diseases. This hypothesis reinforces our previous observation on CMML gene expression [8]. However, in a recent study RAS mutations were distributed independently of the white blood cell count [25].

RB1 deletion, RUNX1 mutation and inv(11)(p15q22) were the only identified alterations in our series of MDCMML. These alterations are neither specific of CMML nor of MD-CMML ( $\mathrm{p}=$ non significant) since we found several (5/13) alterations of RUNX1 in MP-CMMLs. Thus, the molecular biology of MD-CMML remains unclear. Yet, we now know that MD-CMML shares RUNX1 alteration with other diseases. It is tempting to speculate that RUNX1 
alterations are responsible for the dysplasia whereas RAS pathway mutations are responsible for the myeloproliferation. In terms of treatment, CMMLs with a RAS pathway mutation may benefit from drugs able to target the RAS/ RAF/MAPK pathway $[33,34]$ (e.g. sorafenib), while all CMMLs may benefit from therapy restoring RUNX function.

\section{Conclusion}

We have identified two important features of the molecular biology of CMML: i) - RAS pathway mutations are involved, at least, in roughly half of MP-CMML; ii) RUNX1 alterations are frequent in CMML; they may result from mutations or chromosome rearrangements. Importantly, RAS and RUNX1 alterations are not exclusive, showing that, already, two oncogenic hits may coexist at this chronic stage.

\section{Competing interests}

The authors declare that they have no competing interests.

\section{Authors' contributions}

VGB, CA, DS, NV and MJM selected the cases and provided and reviewed the clinical and biological data. VT, $\mathrm{NA}, \mathrm{VR}, \mathrm{SP}, \mathrm{CH}, \mathrm{MBA}$ and $\mathrm{SO}$ generated the sequencing data. JA, VT and MC generated the aCGH data. JA discovered and studied the USP16-RUNX1 fusion. VGB, MJM, $\mathrm{DB}$ and MC supervised the study and wrote the manuscript. All authors approved the study and the manuscript.

\section{Additional material}

\section{Additional File 1}

Clinical and hematological features of the studied CMMLs. This table provides details on disease and patients. CMMLs are classified by a double line according to antecedents. Samples 3 and 37 are from the same patient. CMML: chronic myelomonocytic leukemia. In bold: myeloproliferative CMML and corresponding WBC. AT-CMML(AML-M4): acute transformation of CMML in acute myeloid leukemia of M4 FAB type. MDS: myelodysplasic syndromes. RARS: refractory anemia with ring sideroblasts. EPO: erythropoïetin. WBC: white blood cell count. TA: therapeutic abstention. DGP: dysgranulopoiesis, DMK: dysmegakaryocytopoiesis, DEP: dyserythropoiesis. 2, 95, 75: hematological malignancies were concomitant of the diagnosis of CMML. $8^{*}$ : thrombopenia with a diagnosis of MDS (not done in our Institute). Apparition of anemia 2 weeks before the sampling and then treated with EPO. Variable monocytosis around $1.2 \mathrm{G} / \mathrm{L}$ but unlikely below $1 \mathrm{G} / \mathrm{L}$ at the time of sampling. $25^{*}$ : persistant and stable monocytosis since June $2006(1.2 \mathrm{G} / L)$ but unlikely below $1 \mathrm{G} / \mathrm{L}$ at the time of sampling. $63^{*}$ : mild anemia and thrombopenia with a diagnosis of MDS (not done in our Institute) and then under surveillance. 74*: treated for AML (not in our Institute) in 1992 (chemotherapy) and relapse (AML-M5) in our Institute in 2005

(chemotherapy). The cytological aspect of the bone marrow in January 2007 was CMML type 2. $34^{*}$ : because of the important bone marrow dysplasia and the imprtant cellularity the diagnosis of a acute phase of CMML was made. 80*: antecedent of monocytosis non explored. $88^{*}$ : thrombopenia since 2005 and diagnosis of CMML (2006) made out of our Institute. 106*: stable monocytosis since February 2000. One sister with breast cancer. One brother with head and neck cancer and her mother with colon cancer (deceased).

Click here for file

[http://www.biomedcentral.com/content/supplementary/14712407-8-299-S1.xls]

\section{Additional File 2}

Conditions of DNA sequencing used in this study for various genes. the table provides information (primers, PCR conditions) on sequence experiments conducted in this study.

Click here for file

[http://www.biomedcentral.com/content/supplementary/14712407-8-299-S2.pdf]

\section{Additional File 3}

Primers used for PCR detection of RUNX1 alteration. The table provides information of primers used to detect USP16-RUNX1 fusion. Click here for file [http://www.biomedcentral.com/content/supplementary/14712407-8-299-S3.doc]

\section{Acknowledgements}

We are grateful to the patients who participated in this study. The work has been supported by Inserm, Institut Paoli-Calmettes, and grants from Institut National du Cancer (PHRC 2005 n $^{\circ}$ 24-33, NV), Caisse Primaire d'Assurance Maladie des Professions Libérales de Province (2006, MC), Association pour la Recherche contre le Cancer (ARC Sud 2007, DB) and Fondation de France (comité Leucémie, 2007, DB). 


\section{References}

I. Vardiman JW, Harris NL, Brunning RD: The world health classification (WHO) of myeloid neoplasms. Blood 2002 1 00:2292-2302.

2. Bennett JM, Catovsky D, Daniel MT, Flandrin G, Galton DA, Gralnick $\mathrm{H}$, Sultan C, Cox C: The chronic myeloid leukaemias: guidelines for distinguishing chronic granulocytic, atypical chronic myeloid, and chronic myelomonocytic leukaemia. Proposals by the French-American-British Cooperative Leukaemia Group. Br J Haematol 1994, 84:746-754.

3. Germing U, Gattermann N, Minning H, Heyll A, Aul C: Problems in the classification of CMML-dysplastic versus proliferative type. Leuk Res 1998, 22:87|-878.

4. Nosslinger T, Reisner R, Grüner $H$, Tüchler $H$, Nowotny $H$, Pittermann E, Pfeilstöcker M: Dysplastic versus proliferative CMMLa retrospective analysis of 91 patients from a single institution. Leuk Res 200I, 25:74I-747.

5. Gonzalez-Medina IBJ, Torrequebrada A, Lopez A, Vallespi T, Massague I: Two groups of chronic myelomonocytic leukaemia: myelodysplastic and myeloproliferative. Prognostic implications in a series of a single center. Leuk Res 2002, 26:821-824.

6. Onida F: Pronostics factors in chronic myelomonocytic leukemia: a retrospective analysis of 213 patients. Blood 2002, 99:840-849.

7. Germing U, Strupp C, Knipp S, Kuendgen A, Giagounidis A, Hildebrandt B, Aul C, Haas R, Gattermann N, bennett JM: Chronic myelomonocytic leukemia in the light of the WHO proposals. Haematologica 2007, 92:974-977.

8. Gelsi-Boyer V, Cervera N, Bertucci F, Trouplin V, Remy V, Olschwang S, Chaffanet M, Vey N, Mozziconacci MJ, Birnbaum D: Gene expression profiling separates chronic myelomonocytic leukemia in two molecular subtypes. Leukemia 2007 21:2359-2362

9. Etienne A, Carbuccia N, Adélaide J, Bekhouche I, Rémy V, Sohn C, Sainty D, Gastaut JA, Olschwang S, Birnbaum D, Mozziconacci MJ, Chaffanet $M$ : Rearrangements involving I $2 q$ in myeloproliferative disorders: possible role of HMGA2 and SOCS2 genes. Cancer Genet Cytogenet 2007, I 76:80-88.

10. Adélaide J, Finetti P, Bekhouche I, Repellini L, Geneix J, Sircoulomb F, Charafe-Jauffret E, Cervera N, Desplans J, Parzy D, Schoenmakers E, Viens P, Jacquemier J, Birnbaum D, Bertucci F, Chaffanet M: Integrated profiling of basal and luminal breast cancers. Cancer Res 2007, 67: II565- II575.

II. Barrett MT, Scheffer A, Ben-Dor A, Sampas N, Lipson D, Kincaid R, Tsang P, Curry B, Baird K, Meltzer PS, Yakhini Z, Bruhn L, Laderman $S$ : Comparative genomic hybridization using oligonucleotide microarrays and total genomic DNA. Proc Natl Acad Sci USA 2004, I 0 I: I 7765-17770.

12. Murati A, Adélaide J, Popovici C, Mozziconacci MJ, Arnoulet C, Lafage-Pochitaloff $M$, Sainty D, Birnbaum D, Chaffanet $M$ : A further case of acute myelomonocytic leukemia with inv(8) chromosomal rearrangement and MOZ-NCOA2 gene fusion. Int Mol Med 2003, I 2:423-428.

13. Edkins S, O'Meara S, Parker A, Stevens C, Reis M, Jones S, Greenman C, Davies H, Dalgliesh G, Forbes S, Hunter C, Smith R, Stephens P, Goldstraw P, Nicholson A, Chan TL, Velculescu VE, Yuen ST, Leung SY, Stratton MR, Futreal PA: Recurrent KRAS codon I 46 mutations in human colorectal cancer. Cancer Biol Ther 2006 , 5:928-932

14. Pandit B, Sarkozy A, Pennacchio LA, Carta C, Oishi K, Martinelli S, Pogna EA, Schackwitz W, Ustaszewska A, Landstrom A, Bos JM, Ommen SR, Esposito G, Lepri F, Faul C, Mundel P, López Siguero JP, Tenconi R, Selicorni A, Rossi C, Mazzanti L, Torrente I, Marino B, Dig ilio MC, Zampino G, Ackerman MJ, Dallapiccola B, Tartaglia M, Gelb BD: Gain-of-function RAFI mutations cause Noonan and LEOPARD syndromes with hypertrophic cardiomyopathy. Nat Genet 2007, 39:1007-1012.

15. Razzaque MA, Nishizawa T, Komoike $Y$, Yagi H, Furutani M, Amo R, Kamisago M, Momma K, Katayama H, Nakagawa M, Fujiwara Y, Matsushima M, Mizuno K, Tokuyama M, Hirota H, Muneuchi J, Higashinakagawa T, Matsuoka R: Germline gain-of-function mutations in RAFI cause Noonan syndrome. Nat Genet 2007, 39:1013-1017.

16. Roberts AE, Araki T, Swanson KD, Montgomery KT, Schiripo TA Joshi VA, Li L, Yassin Y, Tamburino AM, Neel BG, Kucherlapati RS: Germline gain-of-function mutations in SOSI cause Noonan syndrome. Nat Genet 2007, 39:70-74.
17. Brems H, Chmara M, Sahbatou M, Denayer E, Taniguchi K, Kato R, Somers R, Messiaen L, De Schepper S, Fryns JP, Cools J, Marynen P, Thomas G, Yoshimura A, Legius E: Germline loss-of-function mutations in SPRED I cause a neurofibromatosis I-like phenotype. Nat Genet 2007, 39: I I 20- I I 26

18. Arai Y, Hosoda F, Kobayashi H, Arai K, Hayashi Y, Kamada N, Kaneko $Y$, Ohki M: The inv( I I)(p I 5q22) chromosome translocation of de novo and therapy-related myeloid malignancies results in fusion of the nucleoporin gene, NUP98, with the putative RNA helicase gene, DDX I0. Blood 1997, 89:3936-3944.

19. Mochizuki N, Shimizu S, Nagasawa T, Tanaka H, Taniwaki M, Yokota J, Morishita K: A novel gene, MELI, mapped to I 36.3 is highly homologous to the MDSI/EVII gene and is transcriptionally activated in $t(1 ; 3)(p 36 ; q 2 I)$-positive leukemia cells. Blood 2000, 96:3209-32। 4

20. Tartaglia L, Gelb BD: Noonan syndrome and related disorders: genetics and pathogenesis. Annu Rev Genomics Hum Genet 2005, 6:45-68.

21. Ferner RE: Neurofibromatosis I. Eur J Human Genet 2007, 15:131-138.

22. Lauchle JO, Braun BS, Loh ML, Shannon K: Inherited predispositions and hyperactive Ras in myeloid leukemogenesis. Pediatr Blood Cancer 2006, 46:579-585.

23. Schubbert S, Shannon K, Bollag G: Hyperactive Ras in developmental disorders and cancer. Nat Rev Cancer 2007, 4:295-308.

24. Bentires-Alj M, Kontaridis M, Neel BG: Stops along the RAS pathway in human genetic disease. Nat Med 2006, I 2:283-285.

25. Tyner JW, Loriaux MM, Erickson H, Eide CA, Deininger J, Macpartlin M, Willis SG, Lange T, Druker BJ, Kovacsovics T, Maziarz R, Gattermann N, Deininger MW: High-throughput mutational screen of the tyrosine kinome in chronic myelomonocytic leukemia. Leukemia 2008

26. Bentires-Alj M, Paez JG, David FS, Keilhack H, Halmos B, Naoki K, Maris JM, Richardson A, Bardelli A, Sugarbaker DJ, Richards WG, Du J, Girard L, Minna JD, Loh ML, Fisher DE, Velculescu VE, Vogelstein B, Meyerson M, Sellers WR, Neel BG: Activating mutations of the noonan syndrome-associated SHP2/PTPN I I gene in human solid tumors and adult acute myelogenous leukemia. Cancer Res 2004, I 5:8816-8820.

27. Tuveson DA, Shaw AT, Willis NA, Silver DP, Jackson EL, Chang S, Mercer KL, Grochow R, Hock H, Crowley D, Hingorani SR, Zaks T, King C, Jacobetz MA, Wang L, Bronson RT, Orkin SH, DePinho RA, Jacks T: Endogenous oncogenic K-ras(G I 2D) stimulates proliferation and widespread neoplastic and developmental defects. Cancer Cell 2004, 5:375-387.

28. Braun BS, Tuveson D, Kong N, Le DT, Rozmus J, Le Beau MM, Jacks TE, Shannon KM: Somatic activation of oncogenic Kras in hematopoietic cells initiates a rapidly fatal myeloproliferative disorder. Proc Natl Acad Sci USA 2004, I 0 I:597-602.

29. Chan IT, Kutok J, Williams IR, Cohen S, Kelly L, Shigematsu H, Johnson L, Akashi K, Tuveson DA, Jacks T, Gilliland DG: Expansion of the genotypic and phenotypic spectrum in patients with KRAS germline mutations. J Clin Invest 2004, I I 3:528-538.

30. Kratz CP, Niemeyer CM, Castleberry RP, Cetin M, Bergsträsser E, Emanuel PD, Hasle H, Kardos G, Klein C, Kojima S, Stary J, Trebo M, Zecca M, Gelb BD, Tartaglia M, Loh ML: The mutational spectrum of PTPNII in juvenile myelomonocytic leukemia and Noonan syndrome/myeloproliferative disease. Blood 2005 , 106:2183-2185.

31. Loh ML, Martinelli S, Cordeddu V, Reynolds MG, Vattikuti S, Lee CM, Wulfert M, Germing U, Haas P, Niemeyer C, Beran ME, Strom S, Lübbert M, Sorcini M, Estey EH, Gattermann N, Tartaglia M: Acquired PTPN I I mutations occur rarely in adult patients with myelodysplastic syndromes and chronic myelomonocytic leukemia. Leuk Res 2005, 29:459-462.

32. Morerio C, Acquila M, Rosanda C, Rapella A, Dufour C, Locatelli F, Maserati $E$, Pasquali F, Panarello C: HCMOGT-I is a novel fusion partner to PDGFRB in juvenile myelomonocytic leukemia with t(5; I 7)(q33;p I I.2). Cancer Res 2004, 64:2649-265 I.

33. Flotho C, Kratz C, Niemeyer CM: Targeting RAS signaling pathways in juvenile myelomonocytic leukemia. Curr Drug Targets 2007, 8:715-725.

34. Flotho C, Steinemann D, Mullighan CG, Neale G, Mayer K, Kratz CP, Schlegelberger B, Downing JR, Niemeyer CM: Genome-wide single-nucleotide polymorphism analysis in juvenile myelomonocytic leukemia identifies uniparental disomy 
surrounding the NFI locus in cases associated with neurofibromatosis but not in cases with mutant RAS or PTPNII. Oncogene 2007, 26:5816-582I.

35. Song WJ, Sullivan MG, Legare RD, Hutchings S, Tan X, Kufrin D, Ratajczak J, Resende IC, Haworth C, Hock R, Loh M, Felix C, Roy DC, Busque L, Kurnit D, Willman C, Gewirtz AM, Speck NA, Bushweller JH, Li FP, Gardiner K, Poncz M, Maris JM, Gilliland DG: Haploinsufficiency of CBFA2 causes familial thrombocytopenia with propensity to develop acute myelogenous leukaemia. Nat Genet 1999, 23:166-175.

36. Imai $Y$, Kurokawa M, Izutsu K, Hangaishi A, Takeuchi K, Maki K, Ogawa S, Chiba S, Mitani K, Hirai H: Mutations of the AMLI gene in myelodysplastic syndrome and their functional implications in leukemogenesis. Blood 2000, 96:3154-3160.

37. Niebuhr B, Fischer M, Tager M, Cammenga J, Stocking C: Gatekeeper function of the RUNXI transcription factor in acute leukemia. Blood Cells Mol Dis 2008, 40:2 II-2I8.

38. Mitelman F, Johansson B, Mertens F: The impact of translocations and gene fusions on cancer causation. Nat Rev Cancer 2007, 7:233-245

39. Kurokawa M: AMLI/RunxI as a versatile regulator of hematopoiesis: regulation of its function and a role in adult hematopoiesis. Int I Hematol 2006, 84: |36-142.

40. Osato M: Point mutations in the RUNXI/AMLI gene: another actor in RUNX leukemia. Oncogene 2004, 23:4284-4296.

4I. Liu H, Holm M, Xie XQ, Wolf-Watz M, Grundstrom T: AMLI/ RunxI recruits calcineurin to regulate granulocyte macrophage colony-stimulating factor by Ets I activation. J Biol Chem 2004, 279:29398-29408.

42. Fujimoto T, Anderson K, Jacobsen SE, Nishikawa SI, Nerlov C: Cdk6 blocks myeloid differentiation by interfering with Runx DNA binding and RunxI-C/EBPalpha interaction. EMBO J 2007, 26:236I-2370.

43. Nagel S, Leich E, Quentmeier H, Meyer C, Kaufmann M, Drexler HG, Zettl A, Rosenwald A, MacLeod RA: Amplification at 7q22 targets cyclin-dependent kinase $\mathbf{6}$ in T-cell lymphoma. Leukemia 2008, 22:387-392.

44. Xinh PT, Tri NK, Nagao H, Nakazato H, Taketazu F, Fujisawa S, Yagasaki F, Chen YZ, Hayashi Y, Toyoda A, Hattori M, Sakaki Y, Tokunag $\mathrm{K}$, Sato $\mathrm{Y}$ : Breakpoints at Ip36.3 in three MDS/AML(M4) patients with $t(1 ; 3)(p 36 ; q 21)$ occur in the first intron and in the 5' region of MELI. Genes Chromosomes Cancer 2003, 36:313-316.

45. Christiansen DH, Desta F, Andersen MK, Pedersen-Bjergaard J: Mutations of the PTPNII gene in therapy-related MDS and AML with rare balanced chromosome translocations. Genes Chromosome Cancer 2007, 46:517-52I.

\section{Pre-publication history}

The pre-publication history for this paper can be accessed here:

http://www.biomedcentral.com/1471-2407/8/299/pre pub

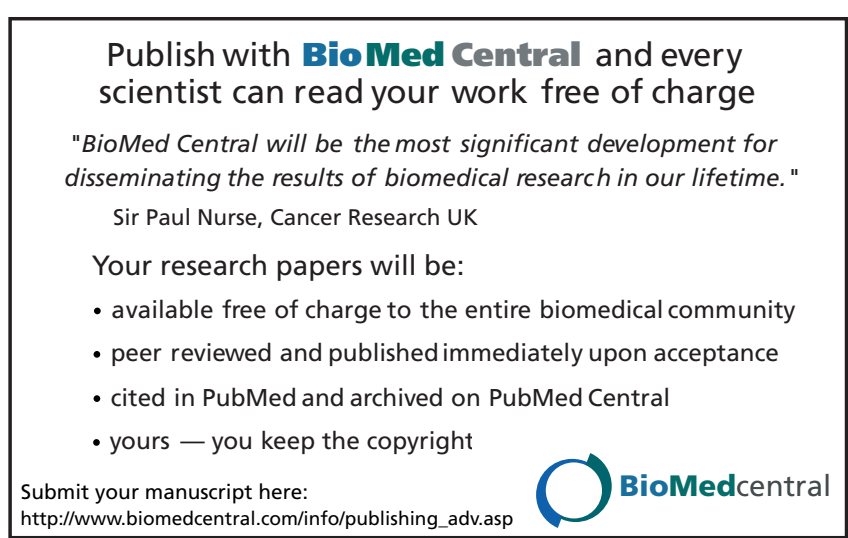

